\title{
Maternal health care utilization and the obstetric outcomes of undocumented women in Finland - a retrospective register-based study
}

\author{
Janita Tasa ${ }^{1 *}$, Ville Holmberg ${ }^{2,3}$, Susanna Sainio ${ }^{4}$, Päivi Kankkunen ${ }^{1}$ and Katri Vehviläinen-Julkunen ${ }^{1,5}$ (B)
}

\begin{abstract}
Background: Undocumented pregnant women constitute a vulnerable group of people who lack equal access to pregnancy care. Previous research has shown that undocumented migrants encounter difficulties in accessing health services, the onset of prenatal care is delayed, and women have an increased risk for infectious diseases. The aim of this study was to describe the use of maternal health care services and the obstetric outcomes of undocumented women in Helsinki, capital city of Finland, in addition to comparing the results with all pregnant women in Finland.

Methods: The study was a retrospective register-based study consisting of data collected between 2014 to 2018 from the electronic medical records of the public maternity clinic and maternity hospital in Helsinki, Finland. The study population consists of 62 individual pregnancies of undocumented women. The results of the study were compared with national data on parturients and deliveries ( $N=47,274$ women) and with prenatal screening tests for infectious diseases ( $N=51,447$ [HIV, HBV], $N=51,446$ [syphilis]).

Results: The majority (91\%) of the undocumented women attended public prenatal care. However, four women received no prenatal care and three women were denied access to care. Undocumented women entered prenatal care later and had fewer visits compared with all pregnant women. The majority (71\%) of the undocumented women received inadequate prenatal care as the number of visits was less than eight. Of the study population, 5\% (3/59) tested positive for HIV, 3\% (2/59) for HBV, and 2\% (1/57) for syphilis. The prevalence of HIV ( $p$-value < 0.001$)$ and HBV ( $p$-value $=0.007$ ) was significantly higher amongst undocumented women compared with all pregnant women.

Conclusions: Undocumented women entered prenatal care later than recommended. Most women received inadequate prenatal care and some of them did not receive prenatal care at all. The prevalence of infectious diseases was significantly higher and the coverage of prenatal screenings deficient amongst undocumented pregnant women.
\end{abstract}

Keywords: Undocumented, Migrant, Prenatal care, Pregnancy, Childbirth, Access to health care, Register-based study

\footnotetext{
* Correspondence: janitatasa@gmail.com

'Department of Nursing Science, University of Eastern Finland, Kuopio, Finland

Full list of author information is available at the end of the article
}

(c) The Author(s). 2021 Open Access This article is licensed under a Creative Commons Attribution 4.0 International License, which permits use, sharing, adaptation, distribution and reproduction in any medium or format, as long as you give appropriate credit to the original author(s) and the source, provide a link to the Creative Commons licence, and indicate if changes were made. The images or other third party material in this article are included in the article's Creative Commons licence, unless indicated otherwise in a credit line to the material. If material is not included in the article's Creative Commons licence and your intended use is not permitted by statutory regulation or exceeds the permitted use, you will need to obtain permission directly from the copyright holder. To view a copy of this licence, visit http://creativecommons.org/licenses/by/4.0/. The Creative Commons Public Domain Dedication waiver (http://creativecommons.org/publicdomain/zero/1.0/) applies to the data made available in this article, unless otherwise stated in a credit line to the data. 


\section{Background}

Every woman should be entitled to special care and assistance during pregnancy, childbirth, and the postnatal period [1-3]. Undocumented pregnant women constitute a particularly vulnerable group of people [4-9] who lack equal access to quality pregnancy care [9]. With continuous prenatal care throughout pregnancy, it is possible to prevent pregnancy complications and arrange proper medical care and guidance when needed [3].

An undocumented migrant is a person who does not have a valid permit to reside in a country. A person may end up as undocumented, for example, as a result of an expired visa or resident permit, a rejected asylum claim, or while waiting for a resident permit [10, 11]. In addition, in Finland, those EU citizens, who do not have a health insurance to cover the costs of medical care, are considered undocumented migrants [10].

Previous research has shown that undocumented migrants encounter great difficulties in accessing health services $[8,11,12]$. Undocumented pregnant women use less health care services compared with other women in the same country $[6,7,9,13-15]$ and the onset of prenatal care is often delayed $[4,5,9,13,16-18]$.

Previous research has also found that undocumented women have an increased risk for sexually transmitted diseases (STD) $[4,17,19-21]$ and majority of them are not adequately screened [4, 17]. According to guidelines of the European Center for Diseases Prevention and Control (ECDC), all migrants from high-prevalence countries ( $>1 \%$ ) should be tested for human immunodeficiency virus (HIV), and pregnant migrants are a priority group for screening. All HIV-positives should immediately be linked to HIV care and treatment programs in accordance with national clinical guidelines. Hepatitis B (HBV) screening of all pregnant migrants is recommended irrespective of the prevalence in the country of origin [22].

In Finland, according to the national legislation, undocumented pregnant women do not have access to preventive maternal health care services, as they are only provided to Finnish residents. However, urgent medical care is provided to everyone regardless of the nationality or the place of residence of the person. Thereby, undocumented women have access to medical care only in the case of pregnancy complications or during childbirth [23]. However, municipalities are entitled to provide wider access to health care for undocumented migrants [24]. Some municipalities, including Helsinki, have decided to provide undocumented pregnant women with access to same public maternal health care services with same expenses as for residents. Basic health care services for undocumented migrants are also provided by health care professionals at voluntarily run 'Global Clinics' in five different cities in Finland, one clinic operating in Helsinki [25].
Since there is evidence that the number of undocumented migrants in Finland has grown in recent years due to an increase in migration [26] and an increase in the number of rejected asylum applications [27], it is highly relevant to recognize and address the health needs of this vulnerable minority group [6]. The present study aimed at identifying a) the characteristics of undocumented pregnant women, b) the utilization of maternal health care services in Helsinki, and c) the obstetric outcomes of undocumented women in addition to comparing the outcomes with all pregnant women in Finland.

\section{Methods \\ Study setting}

The study was conducted in Helsinki, the capital of Finland, a country with a population of 5.5 million [28]. Of the approximately 643,000 residents of Helsinki, $10 \%$ are foreign nationals [29]. In Finland, the estimated number of undocumented migrants is 3000-4000 [10, 27], of whom 100-1000 live in Helsinki [28]. In all of Europe, in 2017, the estimated number of undocumented migrants was 3.9-4.8 million [30].

Since 2013, undocumented pregnant women have had access to maternal health care services in Helsinki [31, 32]. In Finland, women are recommended to have their first prenatal visit during the first pregnancy trimester at gestation weeks 8-10 and to attend eight to ten prenatal care visits during pregnancy [33]. Prenatal care at the public maternity clinic is free of charge [32]. In this study, having fewer than eight prenatal care visits was considered as inadequate prenatal care and having less than four prenatal care visits was considered as clearly inadequate prenatal care.

\section{Study population}

The study population consists of all undocumented pregnant women $(n=60)$ that were identified in the electronic medical records of the public maternity clinics in Helsinki between June 2014 to May 2018. Two undocumented women within the study population were pregnant twice during the study period. Thus, the study covers altogether 62 pregnancies $(N=62)$. The results of the study were compared with national data on parturients, deliveries, and newborns in $2018(N=47,274$ women) and with prenatal screening tests for infectious diseases in $2017(N=51,447$ [HIV, HBV], $\mathrm{N}=51,446$ [syphilis]). The report on the perinatal statistics [34] is publicly available and the data on infectious diseases [35] was obtained from the Finnish Institute for Health and Welfare.

\section{Study design and data}

This study was a descriptive cross-sectional study using retrospective register-based data. The study consists of 
data collected from two distinct electronic medical record systems: 1) Pegasos - an electronic medical record system used in the public maternity clinics of primary health care in Helsinki and 2) Obstetrix - an electronic medical record system used in the public maternity hospitals of specialized medical care in Helsinki and Uusimaa Hospital District. Since 2014, maternity clinics in Helsinki have used a unique statistical code enabling the identification of undocumented pregnant women in Pegasos. Linking data from separate electronic medical records is possible by using identifying information.

The data consists of primary outcome variables: prenatal care utilization (the provider of prenatal care, timing of first prenatal visit, number of all prenatal visits, reason for ending prenatal care, number of missed prenatal visits, and the use of an interpreter) and screening of infectious diseases (HIV, hepatitis $\mathrm{B} / \mathrm{C}$, syphilis, chlamydia trachomatis, methicillin-resistant Staphylococcus aureus [MRSA], extended spectrum beta-lactamases [ESBL], and group B streptococcus [GBS]). In addition, secondary outcome variables: characteristics of the study population (maternal age, parity, smoking habit, use of alcohol, marital status, country of origin, reason for migration, and reason for being in an undocumented situation) and birth outcomes (gestational age at birth, birth outcome, birth weight of the newborn, Apgar score, and neonatal admission).

Individual variables such as first prenatal visit, number of prenatal visits, vacuum extraction, caesarean section, birth weight of the newborn, neonatal admission, screening and positive test result of HIV, HBV, and syphilis were compared between the study population and the comparison group.

\section{Statistical analyses}

The statistical analyses were conducted using IBM SPSS statistics 24 for Mac and Stata 16.1. The data were entered into SPSS anonymously: women in the study population were numbered sequentially (1-62). Descriptive statistics were undertaken presenting frequencies, percentages, mean, standard deviation, minimum, and maximum values of the variables. Individual variables (maternal age, country of origin, timing of first prenatal visit, and number of prenatal visits) were categorized before conducting statistical calculations. In some cases, individual variables lacked values or the information available was unclear. These were entered into SPSS as 'missing information' and excluded from the analyses.

Binominal Exact test was used to calculate the 95\% confidence intervals of the prevalence of HIV, HBV, syphilis and the proportion of vacuum extraction, caesarian section, and neonatal admission of undocumented pregnant women and all pregnant women. $P$-values for differences between the above-mentioned variables in the two groups were calculated using Fisher's Exact test. For continuous variables (first prenatal visit, number of prenatal visits, and birth weight of the newborn) twosample t-test was used to calculate the $95 \%$ confidence intervals and $p$-values between the two groups.

\section{Results \\ Characteristics of the study population}

The main characteristics of the study population are presented in Table 1 . More than half $(56 \% ; 35 / 62)$ of the women were primiparous and their mean age was 28 years $(\mathrm{SD} \pm 4.95$, range $17-42$ years). The majority ( $85 \%$; $45 / 53$ ) of women were married or cohabiting.

Altogether, the women came from 25 different countries - the majority of them originating from Eastern Europe and Russia (36\%; 21/60), Sub-Saharan Africa $(20 \% ; 12 / 60)$, Asia $(18 \% ; 11 / 60)$, and the Middle East $(15 \% ; 9 / 60)$. Family ties $(58 \% ; 35 / 60)$ was clearly the main reason for migration. Women were in an undocumented situation for different reasons. More than half $(57 \% ; 33 / 58)$ of the women were applying for residency, one-fifth $(23 \%$; $13 / 58)$ were EU citizens, and one-tenth $(12 \% ; 7 / 58)$ were illegally in the country (Table 1.$)$

\section{Access to prenatal care}

The majority of the women (91\%; 56/62) attended public prenatal care. Only four women $(6 \% ; 4 / 62)$ had no prenatal visits before delivery. More than one-tenth $(13 \%$; $8 / 62$ ) of the undocumented women had also visited Global Clinic at least once. Three women $(5 \% ; 3 / 60)$ were denied access or continuation of prenatal care by a health care professional (Table 2.)

The onset of prenatal care was delayed - 61\% (34/56) of the undocumented women attended their first prenatal visit during the second or third pregnancy trimester (Table 2). The mean gestation week at the first prenatal visit of undocumented women was 20.5 (SD \pm 10.3 , range $8.0-38.9)$, which was significantly later than compared with all pregnant women $(p<0.001)$. Undocumented women also attended prenatal care less frequently $(\mathrm{p}<0.001)$ compared with all pregnant women, as the mean number of prenatal visits was $5.2(\mathrm{SD} \pm 3.9$, range $0-15$ ) (Table 5).

The majority of undocumented women $(71 \% ; 44 / 62)$ received inadequate $(<8$ visits) prenatal care and of these, $40 \%(25 / 62)$ clearly inadequate prenatal care $(0-3$ visits). Nonetheless, one-tenth $(10 \% ; 6 / 62)$ of the women received more care than was recommended ( $\geq 11$ visits). Interpretation during prenatal visits was used in the majority $(63 \% ; 38 / 60)$ of the situations where it was needed. Though solely professional interpretation was used in one-fourth $(25 \% ; 15 / 60)$ of the prenatal visits (Table 2$)$. 
Table 1 Characteristics of the study population $(N=62)$

\begin{tabular}{|c|c|}
\hline & n (\%) \\
\hline \multicolumn{2}{|l|}{ Age (years) } \\
\hline $17-24$ & $13(21)$ \\
\hline $25-29$ & $28(45)$ \\
\hline $30-34$ & $13(21)$ \\
\hline $35-42$ & $8(13)$ \\
\hline \multicolumn{2}{|l|}{ Parity } \\
\hline 0 & $35(56)$ \\
\hline $1-2$ & $22(35)$ \\
\hline $3-5$ & $5(9)$ \\
\hline \multicolumn{2}{|l|}{ Smoking ${ }^{a, b}$} \\
\hline No & $48(83)$ \\
\hline Continued throughout pregnancy & $6(10)$ \\
\hline Quit smoking when pregnant & $4(7)$ \\
\hline \multicolumn{2}{|l|}{ Alcohol use $e^{a, b}$} \\
\hline No & $54(96)$ \\
\hline Yes & $2(4)$ \\
\hline \multicolumn{2}{|l|}{ Marital status ${ }^{a, b}$} \\
\hline Married/cohabiting & $45(85)$ \\
\hline Relationship, not living together & $5(9)$ \\
\hline Unmarried & $3(6)$ \\
\hline \multicolumn{2}{|l|}{ Country of origin ${ }^{b}$} \\
\hline Eastern Europe and Russia & $21(36)$ \\
\hline Sub-Saharan Africa & $12(20)$ \\
\hline Asia & $11(18)$ \\
\hline Middle East & $9(15)$ \\
\hline North Africa & $5(8)$ \\
\hline South America & $2(3)$ \\
\hline \multicolumn{2}{|l|}{ Reason for migration ${ }^{b}$} \\
\hline Family & $35(58)$ \\
\hline Work & $11(18)$ \\
\hline Study & $4(7)$ \\
\hline Other & $10(17)$ \\
\hline \multicolumn{2}{|c|}{ Reason for being in an undocumented situation ${ }^{a, b}$} \\
\hline Applying for resident permit & $33(57)$ \\
\hline EU citizen & $13(23)$ \\
\hline Illegally in the country & $7(12)$ \\
\hline Student & $2(3)$ \\
\hline Other & $3(5)$ \\
\hline
\end{tabular}

${ }^{\mathrm{a}}$ Missing data excluded

${ }^{\mathrm{b}} n=60$. Two women were pregnant twice. Duplicate removed

\section{Obstetric outcomes}

\section{Screening of infections}

The results of this study showed that three $(5 \% ; 3 / 59)$ undocumented women tested positive for HIV (HIVAgAb), two (3\%; 2/59) for HBV (HBsAg), and one (2\%; 1 /
57) for syphilis (Treponema pallidum antibody). One woman tested positive simultaneously for HIV, HBV, and syphilis. The prevalence of HIV ( $p$-value < 0.001$)$ and HBV (p-value $=0.007$ ) was significantly higher amongst undocumented woman compared with all pregnant women. Of the women, only $43 \%$ (26/60) were screened for hepatitis $\mathrm{C}(\mathrm{HCV})$ antibodies and all samples turned out negative (Table 3 ). In addition, screening tests for multidrug resistant bacteria showed that three (14\%; 3/21) women were colonized with MRSA and two (10\%; 2/21) women were diagnosed with ESBL infection. GBS test came out positive amongst 20\% (9/44) of the women.

\section{Birth outcomes}

The mean gestational age at birth was 40.1 weeks (SD \pm 1.3). The majority of the undocumented women $(87 \%$; 41/47) delivered vaginally. Caesarean section was performed to $13 \%(6 / 47)$ of the women (Table 4). There was no statistically significant difference between the proportion of vacuum assisted deliveries or caesarian sections amongst undocumented women and all pregnant women (Table 5). There were no preterm deliveries $(<37.0)$, low birth weight babies $(<2500 \mathrm{~g})$, nor stillbirths (Table 4).

\section{Discussion}

This is the first study addressing the use of maternal health care services and obstetric outcomes by undocumented women in Finland. This study demonstrates three highly important issues: 1) undocumented women attended maternal health care services in a late stage of pregnancy, 2) the number of prenatal visits was inadequate, and 3) the prevalence of infectious diseases was significantly higher amongst undocumented women.

\section{Access to prenatal care}

In this study, most undocumented women had their first prenatal visit as late as in the second or third pregnancy trimester which is later than the Finnish Institute for Health and Welfare recommends [33]. However, according to the electronic medical records, there was no information available on how long the undocumented women had resided in Finland before accessing their first prenatal visit. Undocumented women had their first prenatal visit even later compared with women in other European countries [4, 5, 9, 16-18]. In addition, undocumented women entered prenatal care on average ten weeks later compared with all pregnant women in Finland [34]. The onset of prenatal care of undocumented women in Helsinki was also delayed compared with the results of de Jonge et al. [5], Wolff et al. [16], and Paquier et al. [18] as their studies showed undocumented women entering prenatal care one to five weeks 
Table 2 Prenatal care utilization $(N=62)$

\begin{tabular}{|c|c|}
\hline & n (\%) \\
\hline \multicolumn{2}{|l|}{ Prenatal care provider } \\
\hline Public maternity clinic & $50(81)$ \\
\hline $\begin{array}{l}\text { Voluntary clinic for undocumented } \\
\text { migrants, Global Clinic (GC) }\end{array}$ & $2(3)$ \\
\hline Partly a maternity clinic and GC & $6(10)$ \\
\hline No prenatal care & $4(6)$ \\
\hline \multicolumn{2}{|l|}{ Prenatal visit before arrival to Finland ${ }^{a}$} \\
\hline Yes & $10(19)$ \\
\hline No & $44(81)$ \\
\hline \multicolumn{2}{|l|}{ Reason for ending prenatal care $a, b$} \\
\hline Yes & $21(35)$ \\
\hline Moved out of Finland & $9(15)$ \\
\hline $\begin{array}{l}\text { Prenatal care continues at a private clinic } \\
\text { or in another city }\end{array}$ & $5(8)$ \\
\hline Care denied & $3(5)$ \\
\hline Unknown reason & $4(7)$ \\
\hline No & $39(65)$ \\
\hline \multicolumn{2}{|l|}{ First prenatal visit ${ }^{a}$} \\
\hline 1. trimester & $22(39)$ \\
\hline 2. trimester & 19 (34) \\
\hline 3. trimester & $15(27)$ \\
\hline \multicolumn{2}{|l|}{ Number of prenatal visits } \\
\hline $0-3$ & $25(40)$ \\
\hline $4-7$ & $19(31)$ \\
\hline $8-10$ & $12(19)$ \\
\hline$\geq 11$ & $6(10)$ \\
\hline \multicolumn{2}{|l|}{ Number of missed prenatal visits ${ }^{a}$} \\
\hline 0 & $38(70)$ \\
\hline 1 & $7(13)$ \\
\hline 2 & $5(9)$ \\
\hline 3 & $4(8)$ \\
\hline \multicolumn{2}{|l|}{ Use of interpreter during prenatal visit ${ }^{a}$} \\
\hline Family member & $15(25)$ \\
\hline Professional interpreter ${ }^{c}$ & $15(25)$ \\
\hline Both family member and professional interpreter & $8(13)$ \\
\hline Interpreted not needed & $19(32)$ \\
\hline Interpreter not used & $3(5)$ \\
\hline
\end{tabular}

aissing data excluded

b Two of the study population women were still pregnant during the data collection

${ }^{c}$ Including translation via phone

later in comparison to other women in the same country.

In addition to delayed prenatal care, the results of this study showed undocumented women receiving inadequate prenatal care. This is consistent with previous research $[6,7,9,13-15]$. Moreover, the average number of prenatal visits of undocumented women was inadequate compared with the Finnish Institute for Health and Welfare's recommendation of eight to ten visits [33], in addition to the World Health Organization's recommendation of minimum of eight visits [3]. Undocumented women in Helsinki had eight prenatal visits less than the average of all pregnant women in Finland in 2018 [34]. This study showed that almost one-fifth of the undocumented women had visited a health care professional at least once before arrival to Finland. Nevertheless, we suggest that the undocumented women received inadequate prenatal care as there was no reliable information or documentation available of these visits.

An additional finding of concern is that four women in this study did not receive any prenatal care. Similar results have been found in Canada, where 7\% [14], and in the Netherlands, where nearly one-fifth of the undocumented women received no prenatal care [4]. In addition, this study showed that three women were denied access or continuation of care by a health care professional. Previous research from Norway and Sweden, and a report from the Swedish Agency for Public Management have found similar tendencies [8, 36, 37].

As undocumented women have had access to public maternal health care in Helsinki already since 2013 [31], it is necessary to consider why women access these services in such a late stage of pregnancy. In this study, inadequate prenatal care can partially be explained by the late onset of prenatal care, women ending prenatal care, and women not showing up for booked appointments. Previous research also suggests that lack of information on the right to health services, fear $[4,7,36]$, unfamiliar health care system, and poor financial situation $[4,11]$ may lead to under-utilization of health care services. It is also worth highlighting that language barriers may complicate the access to and quality of care [12], in addition to the delivery of maternity care [9]. In this research, solely professional interpretation was used only in onefourth of the prenatal visits, which is less frequently compared with a recent study conducted in Sweden, where professional interpretation was used in $82 \%$ of the prenatal visits of asylum seeker and undocumented pregnant women [9]. Lastly, it needs to be considered that the lack of knowledge amongst health care professionals on the official guidelines on the legal rights of undocumented migrants may hinder the access to prenatal care $[7,8,37]$.

The results of this study, amongst previous research $[4,9,14,17]$, underlines the importance of early access to maternal health care services for undocumented women. There is evidence to suggest that by expanding access to prenatal care, the utilization $[15,38]$ and the 
Table 3 The prevalence of infectious diseases between undocumented women $(n=60)$ and all pregnant women $(N=51,447)$ in 2017

\begin{tabular}{|c|c|c|c|c|c|c|}
\hline & \multicolumn{3}{|l|}{ Undocumented women } & \multicolumn{3}{|c|}{ All pregnant women } \\
\hline & Screening completed $\mathrm{n}(\%)$ & Positives $\mathbf{n}$ & Prevalence $\%(95 \% \mathrm{Cl})$ & Positives $\mathbf{n}$ & Prevalence $\%(95 \% \mathrm{Cl})$ & $p$-value ${ }^{a}$ \\
\hline HIV & $59(98)$ & 3 & $5.1(1.1-14.1)$ & 42 & $0.08(0.06-0.1)$ & $<0.001$ \\
\hline HBV & $59(98)$ & 2 & $3.4(0.4-11.7)$ & 110 & $0.2(0.2-0.3)$ & 0.007 \\
\hline Syphilis & $57(95)$ & 1 & $1.8(0.04-9.4)$ & 43 & $0.08(0.06-0.1)^{b}$ & 0.048 \\
\hline $\mathrm{HCV}$ & $26(43)$ & 0 & $0(-)$ & - & - & - \\
\hline Chlamydia trachomatis $^{c}$ & $17(28)$ & 1 & $5.9(-)$ & - & - & - \\
\hline
\end{tabular}

Register data on all pregnant women who underwent infectious disease screening in 2017 [35]

Duplicate pregnancies excluded from the analysis

${ }^{a}$ Fisher's Exact test

${ }^{b} \mathrm{~N}=51,446$

${ }^{c}$ Not part of routine prenatal screening. Tested if symptoms occurred

quality of care increased, and undocumented women were more likely to receive adequate prenatal care [38]. Furthermore, late access to health services may implicate higher financial costs as timely treatment in the primary health care setting has shown to be more cost-effective compared with urgent medical care [39, 40].

As the legal right to maternity health care is not sufficient to guarantee access to prenatal care [9], there is a need to develop diverse and innovative ways to reach undocumented women to increase access to care. Further, the importance of policy-makers and health care managers' responsibility in ensuring that health care professionals receive sufficient training and knowledge on the rights and practices of care of undocumented pregnant women should be emphasized $[8,37]$.

Table 4 Birth outcomes of undocumented pregnant women $(n=47)$

\begin{tabular}{|c|c|c|c|c|c|}
\hline & n (\%) & Mean & SD & Min & Max \\
\hline Gestational age at birth (gw) & & 40.1 & 1.3 & 37.1 & 42.3 \\
\hline \multicolumn{6}{|l|}{ Birth outcome } \\
\hline Spontaneous vaginal delivery & $33(70)$ & & & & \\
\hline Vacuum extraction & $8(17)$ & & & & \\
\hline Caesarean section & $6(13)$ & & & & \\
\hline Still birth & $0(0)$ & & & & \\
\hline Birth weight (g) & & 3438 & 380.6 & 2642 & 4125 \\
\hline Apgar score at $5 \mathrm{~min}^{\mathrm{a}}$ & & 9 & 0.9 & 6 & 10 \\
\hline \multicolumn{6}{|l|}{ Umbilical cord pH } \\
\hline$<7.10$ & $1(2)$ & & & & \\
\hline $7.10-7.20$ & $14(30)$ & & & & \\
\hline$>7.20$ & $32(68)$ & & & & \\
\hline Neonatal admission $^{\mathrm{b}}$ & $3(6)$ & & & & \\
\hline
\end{tabular}

${ }^{a}$ Missing data excluded

${ }^{b}$ Respiratory distress and hypoglycemia reasons for admission to neonatal intensive care unit

\section{Screening of infections}

There is only scarce research on the prevalence of infectious diseases amongst undocumented pregnant women. In this study, the prevalence of HIV and HBV was significantly higher amongst undocumented women compared with all pregnant women. The results are in line with previous research that has found the prevalence of infectious diseases higher amongst undocumented women compared with other migrant or native women in the same country $[5,17,19,20]$.

Interestingly, this study found that the prevalence of HIV amongst undocumented pregnant women in Helsinki was higher than what was found by Wolff et al. [16] $(0.6 \%, n=161)$ and Wendland et al. [17] $(1.5 \% ; n=$ 132). In contrast, the prevalence of HBV was less amongst undocumented women in this study than what Wendland et al. [17] had found $(6.5 \% ; N=92)$. The prevalence of infections detected amongst the undocumented women in this study were high also compared with data from asylum seekers in Finland (HIV 0.3\%; $n=45$, HBV $1.6 \% ; n=275$ ) [41] and asylum seekers in Italy (HIV $1.6 \% ; n=5$, syphilis $0.7 \% ; n=2$ ) [42]. Though, it is possible that these discrepant observations are due to different backgrounds in different populations or the small sample size in all the studies.

The Finnish Institute for Health and Welfare recommends screening for HIV, HBV, and syphilis in the early stage of pregnancy [33]. In addition, the official guidelines for prenatal and obstetric care issued by the Helsinki and Uusimaa hospital district recommends screening of HCV amongst undocumented women [43]. It is noteworthy that more than half of the women were not tested for $\mathrm{HCV}$. The reason for low coverage of $\mathrm{HCV}$ testing may be explained by the fact that the guideline is not a national regulation, merely a local recommendation, and the fact that the health care professionals may not have been aware of the specific guideline. Restricting access to preventive and timely 
Table 5 Obstetric outcomes between undocumented women $(N=62)$ and all pregnant women $(N=47,274)$ in 2018

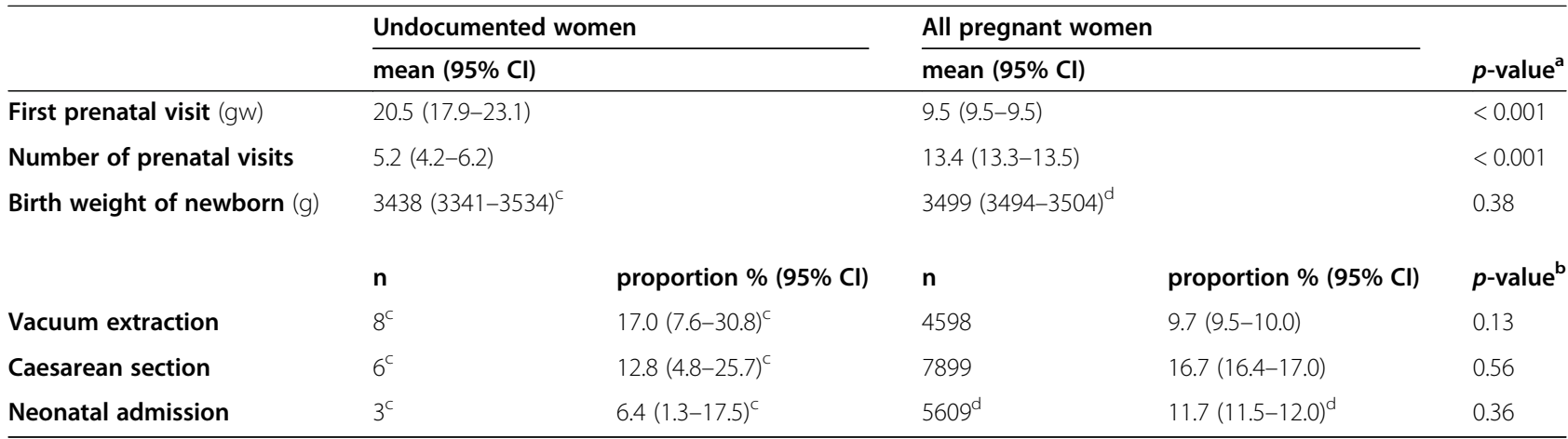

Register data on parturients, deliveries, and newborns in 2018 [34]

${ }^{\text {a } T w o ~ s a m p l e ~ t-t e s t ~}$

${ }^{b}$ Fisher's Exact test

$c n=47$ (undocumented parturients and live born neonates)

${ }^{d}=47,777$ (live born neonates)

health care is not only unequal but may lead to adverse consequences for public health due to limited or late screening and treatment of communicable infections and mother-to-child transmissions [17].

\section{Strengths and limitations}

This study was a register-based study conducted as a census study and the study population comprised exclusively of undocumented women. The study was conducted in Helsinki, the capital of Finland, where most undocumented migrants are assumed to reside. The heterogeneous study population represents well the population of undocumented pregnant women met in the maternity health care services and at Global Clinic in Helsinki. The reliability of this study is increased by the fact that Finnish health registers have been found to have good coverage, high validity, and data quality [44]. The accuracy of the data used is enhanced by the fact that many of the variables already existed as such in the electronic medical records of both primary (Pegasos) and specialized health care (Obstetrix).

The limitation of the study is its relatively small study population. However, it must be considered that the number of all undocumented migrants in all of Finland is estimated to be only $3000-4000[10,27]$. The possibility that some undocumented women may have been left outside of the study cannot be excluded. This could be due to a failure to register them under the proper statistical code (primary health care) or due to the legal status of migrants not being registered at all (specialized health care).

\section{Conclusions}

This study indicates that the onset of prenatal care of undocumented pregnant women was delayed. In addition, undocumented pregnant women received inadequate prenatal care and some of them did not receive prenatal care at all. The prevalence of HIV and HBV was significantly higher amongst undocumented women than in the general parturient population. The results also reveal that the coverage of prenatal screenings amongst undocumented pregnant women was inadequate.

Delayed onset of prenatal care may adversely affect the obstetric outcome and the early detection of possible obstetric complications. In addition, screening of infections, the detection, and treatment of infectious disease may be delayed. This could lead to an increased risk of mother-to-child transmissions. Consequently, undocumented women should be guaranteed extensive, equal, and timely access to prenatal care to ensure a safe and positive pregnancy outcome.

\section{Abbreviations}

ECDC: European Centre for Disease Prevention and Control; ESBL: Extended spectrum beta-lactamases; GC: Global Clinic, voluntary health clinic for undocumented migrants; GBS: Group B streptococcus; GW: Gestation week, the gestational age is described as completed weeks of pregnancy; HBV: Hepatitis B virus; HCV: Hepatitis C virus; HIV: Human immunodeficiency virus; MRSA: Methicillin-resistant Staphylococcus aureus; STD: Sexually transmitted diseases

\section{Acknowledgements}

JT thanks Johanna Etie for providing assistance with the use of the electronic medical record system Pegasos. The authors thank Emmi Närvänen and Eveliina Karhu for reviewing the English language.

\section{Authors' contributions}

JT, KV-J, and PK planned and designed the study. JT reviewed the literature, collected the data, and conducted the statistical analyses with the support of $\mathrm{VH}$, and in the supervision of KV-J and PK. JT drafted the manuscript with the support of SS. All authors commented, revised, and approved the final manuscript.

Funding

The Foundation for Municipal Development sr. granted JT a scholarship to support the study.

Availability of data and materials

The data on undocumented women analyzed in the study is available from the corresponding author on reasonable request. The data on perinatal statistics of parturients, deliveries, and newborns in 2018 that support the 
findings of the study is publicly available from the Finnish Institute for Health and Welfare at http://www.julkarifi/bitstream/handle/10024/138998/Tr49_19. pdf? sequence $=5$ \&isAllowed $=y$. The data on infectious diseases of all pregnant women in 2017 that support the findings of the study was obtained from the Finnish Institute for Health and Welfare. The data is not publicly available.

\section{Ethics approval and consent to participate}

The research permit for the study was obtained from the Helsinki and Uusimaa Hospital District (Ref March 2018) and the Social Services and Health Care Division of Helsinki (Ref April 2018). In Finland, an ethics review statement is not required for scientific research including solely register data (Finnish National Board on Research Integrity TENK, https://tenk.fi/sites/tenk. fi/files/lhmistieteiden_eettisen_ennakkoarvioinnin_ohje_2019.pdf). Processing of personal data without an informed consent of participants is permitted by law when conducting scientific research (Data Protection Act 1050/2018, https://www.finlex.fi/en/laki/kaannokset/2018/en20181050.pdf). All methods in the research were performed in accordance with the guidelines of the Finnish National Board on Research Integrity TENK and the legislation.

\section{Consent for publication}

Not applicable.

\section{Competing interests}

The authors declare that they have no competing interests.

\section{Author details}

'Department of Nursing Science, University of Eastern Finland, Kuopio, Finland. ${ }^{2}$ Inflammation Center, Infectious Diseases, Helsinki University Hospital, Helsinki, Finland. ${ }^{3}$ Clinicum, Department of Medicine, University of Helsinki, Helsinki, Finland. ${ }^{4}$ Finnish Red Cross Blood Service, Helsinki, Finland. ${ }^{5}$ Clinical Development, Education and Research Centre, Kuopio University Hospital, Kuopio, Finland.

\section{Received: 12 November 2020 Accepted: 10 February 2021 Published online: 06 March 2021}

\section{References}

1. United Nations. Universal Declaration of Human Rights. https://www.un.org/ en/universal-declaration-human-rights/. Accessed 10 March 2020.

2. Council of Europe. Human rights of irregular migrants. http://assembly.coe int/nw/Xml/XRef/Xref-XML2HTML-en.asp?fileid=17456\&lang=en.http://a ssembly.coe.int/nw/Xml/XRef/Xref-XML2HTML-en.asp?fileid=17456\&lang=en. Accessed 10 March 2020

3. World Health Organization. WHO recommendations on antenatal care for a positive pregnancy experience. 2016. https://apps.who.int/iris/bitstream/ha ndle/10665/250796/9789241549912-eng.pdf?sequence=1. Accessed 15 April 2020.

4. Schoevers M, Van den Muijsenbergh M, Lagro-Janssen A. Illegal female immigrants in the Netherlands have unmet needs in sexual and reproductive health. J Psychosom Obstet Gynaecol. 2010;31(4):256-64.

5. De Jonge A, Rijnders M, Agyemang C, van der Stouwe R, den Otter J, den Muijsenbergh $V$, Buitendijk S. Limited midwifery care for undocumented women in the Netherlands. J Psychosom Obstet Gynaecol. 2011;32(4):182-8.

6. Munro K, Jarvis K, Munzo M, D'Souza V, Graves L. Undocumented pregnant women: what does the literature tell us? J Immigrant Minority Health. 2013; 15:281-91

7. de Jong L, Pavlova M, Winters $M$, Rechel B. A systematic literature review on the use and outcomes of maternal and child healthcare services by undocumented migrants in Europe. Eur J Pub Health. 2017;27(6):990-7.

8. Barkensjö M, Greenbrook J, Rosenlundh J, Ascher H, Elden H. The need for trust and safety inducing encounters: a qualitative exploration of women's experiences of seeking perinatal care when living as undocumented in Sweden. BMC Pregnancy Childbirth. 2018;18(1):217

9. Liu C, Ahlberg M, Hjern A, Stephansson O. Perinatal health of refugee and asylum-seeking women in Sweden 2014-17: a register-based cohort study. Eur J Pub Health. 2019;29(6):1048-55.

10. Ministry of Health and Social Affairs. Health care of undocumented persons. 2013. https://stm.fi/en/article/-/asset_publisher/health-care-ofundocumented-persons. Accessed 15 April 2020.
11. Smith A, LeVoy M. Cities of rights: ensuring health care for undocumented residents. PICUM. 2017. https://picum.org/wp-content/uploads/2017/11/ CityOfRights_Health_EN.pdf. Accessed 15 April 2020.

12. Almeida LM, Caldas J, Ayres-de-Campos D, Salcedo-Barrientos D, Dias S. Maternal healthcare in migrants: a systematic review. Matern Child Health J. 2013;17(8):1346-54.

13. Castañeda $\mathrm{H}$. Illegality as risk factor: a survey of unauthorized migrant patients in a Berlin clinic. Soc Sci Med. 2009;68(8):1552-60.

14. Wilson-Mitchell K, Rummens JA. Perinatal outcomes of uninsured immigrant, refugee and migrant mothers and newborns living in Toronto, Canada. Int J Environ Res Public Health. 2013;10(6):2198-213.

15. Wherry L, Fabi R, Shickedanz A, Saloner B. State and federal coverage for pregnant immigrants: prenatal care increased, no change detected for infant health. Health Aff. 2017;36(4):607-15.

16. Wolff H, Epiney M, Lourenco A, Costanza M, Delieutraz-Marchand J, Andreoli N, Dubuisson JB, Gaspoz JM, Irion O. Undocumented migrants lack access to pregnancy care and prevention. BMC Public Health. 2008;8:93.

17. Wendland A, Ehmsen BK, Lenskjold V, Astrup B, Mohr M, Williams C, Cowan S. Undocumented migrant women in Denmark have inadequate access to pregnancy screening and have a higher prevalence hepatitis B virus infection compared to documented migrants in Denmark: a prevalence study. BMC Public Health. 2016;16:426.

18. Paquier $L$, Barlow $P$, Paesmans $M$, Rozenberg S. Do recent immigrants have similar obstetrical care and perinatal complications as long-term residents? A retrospective exploratory cohort study in Brussels. BMJ Open. 2020. https://doi.org/10.1136/bmjopen-2019-029683.

19. Wolff H, Lourenço A, Bodenmann P, Epiney M, Uny M, Andreoli N, Irion O, Gaspoz JM, Dubuisson JB. Chlamydia trachomatis prevalence in undocumented migrants undergoing voluntary termination of pregnancy: a prospective cohort study. BMC Public Health. 2008:8:391.

20. Dias S, Gama A, Pingarilho M, Simões D, Mendão L. Health services use and HIV prevalence among migrant and national female sex workers in Portugal: are we providing the services needed? AIDS Behav. 2017;21:2316-21.

21. Frati E, Fasoli E, Martinelli M, Colzani D, Bianchi S, Carnelli L, Amendola A, Oliviani P, Tanzi E. Sexually transmitted infections: a novel screening strategy for improving women's health in vulnerable populations. Int J Mol Sci. 2017;18(6):1311.

22. European Centre for Disease Prevention and Control. Public health guidance on screening and vaccination for infectious diseases in newly arrived migrants within the EU/EEA. 2018. doi: https://doi.org/10.2900/1 54411. Accessed 25 May 2020.

23. Health Care Act 1326/2010. https://www.finlex.fi/en/laki/kaannokset/2010/ en20101326_20131293.pdf. Accessed 15 April 2020.

24. Ministry of Health and Social Affairs. Healthcare and social welfare for illegal residents. 2017. https://stm.fi/en/social-security-and-services-of-asylumseekers-in-finland/healthcare-and-social-welfare-for-illegal-residents. Accessed 15 April 2020.

25. Global Clinic. Health care for people with an irregular immigration status in Finland. General information http://muw.globalclinicfi/en/. Accessed 11 July 2020.

26. Salmi H, Tiittala P, Lundqvist T, Mönttinen A, Sainio S, Aali H, Holmberg V. Kuinka hoidan paperitonta potilasta? [Providing health care for undocumented patients]. Suomen Lääkärilehti. 2016;12-13(71):915-22.

27. Jauhiainen J, Gadd K, Jokela J. Paperittomat Suomessa 2017. [Undocumented migrants in Finland in 2017]. 2018. http://urmi.fi/wpcontent/uploads/2018/01/PAPERITTOMAT-SUOMESSA-2017.pdf. Accessed 11 July 2020.

28. Digital and Population Data Services Agency. The personal identity code. https://dvv.fi/en/personal-identity-code. Accessed 11 July 2020.

29. Helsinki City Executive Office. Statistical yearbook of Helsinki. 2020. https:// www.avoindata.fi/data/en_GB/dataset/helsingin-tilastollinen-vuosikirja. Accessed 11 July 2020

30. Connor P, Passel J. Europe's unauthorized immigrant population peaks in 2016, then levels off. Pew Research Center 2019. https://www.pewresearch. org/global/2019/11/13/europes-unauthorized-immigrant-population-peaksin-2016-then-levels-off/. Accessed 11 July 2020.

31. Social Services and Health Care Division of the city of Helsinki. Ulkomailta tulevien oikeus hoitoon, maksut ja korvaukset. PYSY011. 2014. Not publicly available.

32. City of Helsinki. Social and health care services for undocumented people in Helsinki. https:/www hel fi/helsinki/en/administration/administration/ services/service-description?id=3677. Accessed 11 July 2020. 
33. Klemetti R, Hakulinen-Viitanen T. Äitiysneuvolaopas: Suosituksia äitiysneuvolatoimintaan. Terveyden ja Hyvinvoinnin laitos. Tampere: Juvenes Print - Suomen yliopistopaino; 2013.

34. Kiuru S, Gissler M. Perinataalitilasto - synnyttäjät, synnytykset ja vastasyntyneet 2018. [Perinatal statistics - parturients, delivers and newborns 2018]. 2019. http:/www.julkari.fi/bitstream/handle/10024/138998/ Tr49_19.pdf?sequence=1\&isAllowed=y. Accessed 10 May 2020.

35. Liitsola K: Statistical information from the Finnish Institute for Health and Welfare on the number of HIV, HBV, and syphilis infections amongst pregnant women in Finland in 2017, unpublished.

36. Kvamme E, Yterhus S. Barriers to health care access among undocumented migrant women in Norway. Soc Health Vulnerability. 2015;6(1). https://doi. org/10.3402/shv.v6.28668.

37. Statskontoret. Vård till papperslösa. Slutraportt av uppdraget att följa upp lagen om vård till personer som vistas i Sverige utan tillstånd. 2016. http:// www.statskontoret.se/globalassets/publikationer/2016/201611.pdf. Accessed 10 May 2020.

38. Swartz J, Hainmueller J, Lawrence D, Rodriguez M. Expanding prenatal care to unauthorized immigrant women and the effects on infant health. Obstet Gynecol. 2017;130(5):938-45.

39. European Union Agency for Fundamental Rights. Cost of exclusion from healthcare - the case of migrants in an irregular situation. 2015; doi:https:// doi.org/10.2811/23637.

40. Trummer U, Novak-Zezula S, Renner AT, Wilczewska I. Cost analysis of health care provision for irregular migrants and EU citizens without insurance. Center for health and migration 2015. https://eea.iom.int/publications/cost-a nalysis-health-care-provision-irregular-migrants-and-eu-citizens-without. Accessed 12 June 2020.

41. Tiittala P, Tuomisto K, Puumalainen T, Lyytikäinen O, Ollgren J, Snellman O, Helve O. Public health response to large influx of asylum seekers: implementation and timing of infectious disease screening. BMC Public Health. 2018;18:1139.

42. Cuomo G, Franconi I, Riva N, Bianchi A, Digaetano M, Santoro A, Codeluppi M, Bedini A, Guaraldi G, Mussini C. Migration and health: a retrospective study about the prevalence of HBV, HIV, HCV, tuberculosis and syphilis infections amongst newly arrived migrants screened at the infectious diseases unit of Modena, Italy. J Infect Public Health. 2019;12(2):200-4.

43. Haikarakansio: Synnytysten hoito-ohjeet. 2018, unpublished.

44. Sund R. Quality of the Finnish hospital discharge register: a systematic review. Scand J Public Health. 2012;40(6):505-15.

\section{Publisher's Note}

Springer Nature remains neutral with regard to jurisdictional claims in published maps and institutional affiliations.

Ready to submit your research? Choose BMC and benefit from:

- fast, convenient online submission

- thorough peer review by experienced researchers in your field

- rapid publication on acceptance

- support for research data, including large and complex data types

- gold Open Access which fosters wider collaboration and increased citations

- maximum visibility for your research: over $100 \mathrm{M}$ website views per year

At $\mathrm{BMC}$, research is always in progress.

Learn more biomedcentral.com/submissions 